\section{(CC) BY 4.0}

\title{
Low Level of Antithrombin III as a Warning Sign for Developing Thrombotic Complications in Surgical Patients
}

Zolotukhin Konstantin Nikolaevich -

Candidate of Medical Sciences,

Chief of ICU \& Anesthesiology

Department,

e-mail:lkbros5@mail.ru

Krüger Philipp -

MD, Physician of

anesthesiology

at the Departement

of Anesthesiology,

Intensive Care and Pain

Therapy, e-mail: philipp.

krueger@klinikumdo.de,

orcid.org/0000-0002-0524

7526

Samorodov Aleksandr

Vladimirovich -

Candidate of Medical Sciences,

Physician of the Department of

ICU \& Anesthesiology, e-mail:

AVSamorodov@gmail.com

orcid.org/0000-0001-9302-

$499 X$

\author{
Konstantin N. Zolotukhin', Philipp Krüger², Aleksandr V. Samorodov'
}

${ }^{1}$ G.G. Kuvatov Republican Clinical Hospital, 132 Dostoevsky str., Ufa, 450005, Russian Federation
${ }^{2}$ Klinikum Dortmund gGmbH, 40 Beurhausstraße, Dortmund, 44137, Germany
Contacts: Samorodov Aleksandr Vladimirovich, e-mail: AVSamorodov@ gmail.com

\section{Summary}

Introduction. Pulmonary embolism (PE), being the most severe embolic complication, is characterised by low predictability, high mortality and incapacitation rates as well as a correspondingly high economic cost of therapy and aftercare. In this connection, the main purpose of our work is to find a warning for PE development in non-cardiosurgical patients that have undergone intensive therapy under conditions of general surgical ICU, among the indicators of the haemostasis system.

Materials and methods. Based at the anaesthesiology and emergency surgical department № 1 of the Kuvatov Republic Clinical Hospital (Russia), the researchers carried out an analysis of the haemostasis system in 430 patients hospitalised between 2010 and 2014. The functional activity of platelets was studied using a Biola 230LA laser platelet aggregation analyser (Russia). The determination of circulating aggregates was conducted using the Wu - Hoak method. Thromboelastography was carried out using a TEG 5000 Thromboelastograph (USA). A Stago STA Compact automated selective haemostasis analyser (France) was used to register indicators that characterise the state of endothelium, the haemostatic coagulation element and thrombosis and fibrinolysis markers.

Results. Univariate analysis demonstrated a connection between nosocomial episodes of thrombosis and the following factors: emergency surgery (OR 9.1, $p<0.01$ ), peripheral vessel disease (OR 13.5, $p=0.01$ ), collapse development in pre-operation period (OR 30, $p<0.01$ ), high content of D-dimers (OR 30, $p<0.01$ ) and low content of AT III (OR 13.5, $p=0.01)$. The results of multifactor analysis show that the significant diagnostic criteria are high $\mathrm{D}$-dimer content and low AT III venous blood activity.

Conclusion. A determination of high risks will enable the incidence of pulmonary embolism to be to minimised as well as provide a timely assessment of the efficiency of preventive measures carried out.

Keywords: thromboembolism, pulmonary artery, platelet aggregation, fibrinolysis, surgical haemostasis

For citation: Zolotukhin K.N., Krüger Ph., Samorodov A.V. Low Level of Antithrombin III as a Warning Sign for Developing Thrombotic Complications in Surgical Patients. Creative Surgery and Oncology. 2018;8(1):52-56. https://doi. org/10.24060/2076-3093-2018-8-1-52-56 


\section{Низкий уровень антитромбина III как предиктор развития тромботических осложнений у пациентов хирургического профиля}

К.Н. Золотухин', Ф. Крюгер², А.В. Самородов'

\author{
${ }^{1}$ Республиканская клиническая больница им. Г.Г. Куватова, Россия, 450005, Уфа, ул. Достоевского, 132 \\ ${ }^{2}$ Клиника Дортмунда, Германия, 44137, Дортмунд, Берхауштрассе, 40 \\ Контакты: Самородов Александр Владимирович, e-mail: AVSamorodov@gmail.com
}

\section{Резюме}

Введение. Тромбоэмболия легочной артерии (ТЭЛА), являясь самым грозным эмболическим осложнением, характеризуется низкой вероятностью прогноза, высоким процентом летальности, смертности и инвалидизации и, как следствие, высокой экономической стоимостью лечения и реабилитации. В этой связи основной целью нашей работы послужил поиск предикторов развития ТЭЛА у пациентов не кардиохирургического профиля, получавших интенсивную терапию в условиях общехирургического ОРИТ, среди показателей системы гемостаза.

Материалы и методы. На базе анестезиолого-реанимационного отделения № 1 хирургического профиля ГБУЗ Республиканская клиническая больница имени Г.Г. Куватова (г. Уфа) был проведен анализ показателей системы гемостаза 430 пациентов, госпитализированных в период с 2010 по 2014 г. Исследование агрегации тромбоцитов осуществляли с помощью лазерного анализатора агрегации тромбоцитов «Биола 230LA». Определение циркулирующих агрегатов проводили по методу Wu - Hoak. Показатели, характеризующие состояние эндотелия, активность коагуляционного звена гемостаза и маркеры процессов тромбообразования и фибринолиза при действии изучаемых веществ, регистрировали на автоматизированном селективном анализаторе гемостаза STA Compact («Ф. Хоффманн - Ля Рош Лтд», Франция).

Результаты. Однофакторный анализ выявил наличие связи между госпитальными эпизодами тромбоза и следующими факторами: экстренное хирургическое вмешательство (OR 9,1, $p<0,01)$, заболевание периферических сосудов (OR 13,5, $p=0,01)$, развитие шока в дооперационном периоде (OR 30, $p<0,01$ ), высокое содержание D-димеров (OR 30, $p<0,01)$ и низкое содержание AT III (OR 13,5, $p=0,01)$. По результатам многофакторного анализа значимыми диагностическими критериями являются высокое содержание D-димеров и низкая активность AT III венозной крови.

Заключение: установленная закономерность позволяет верифицировать высокие риски в отношении вероятности тромбоэмболии легочной артерии и своевременно оценивать эффективность проводимых профилактических мер.

Ключевые слова: тромбоэмболия, легочная артерия, агрегация тромбоцитов, фибринолиз, хирургический гемостаз

Для цитирования:Золотухин К.Н., Крюгер Ф., Самородов А.В. Низкий уровень антитромбина III как предиктор развития тромботических осложнений у пациентов хирургического профиля. Креативная хирургия и онкология. 2018;8(1):52-56. https://doi.org/10.24060/2076-3093-2018-8-1-52-56
Золотухин Константин Николаевич К.м.н., заведующий отделением $A P O 1$ e-mail:Ikbros5@mail.ru

Крюгер Филипп врач анестезиологреаниматолог отделения анестезиологии и интенсивной терапии, e-mail:philipp.krueger@ klinikumdo.de, orcid.org/0000-0002-0524-7526

Самородов Александр Владимирович к.м.н., врач анестезиологреаниматолог APO 1, e-mail: AVSamorodov@gmail.com, orcid.org/0000-0001-9302-499X 


\section{Introduction}

Pulmonary embolism (PE), the most severe embolic complication, is characterised by low predictability, high mortality and incapacitation rates as well as a correspondingly high economic cost of therapy and aftercare [1]. A statistical series of population-based studies was used to determine the main reasons and risk factors for pulmonary embolism [2-6], and to develop clinical practice guidelines to prevent thromboembolic complications. However, despite the efficiency of

\begin{tabular}{|c|c|}
\hline Indicator & Value \\
\hline$A g e \pm S D$, years & $58.9 \pm 19.6$ \\
\hline Male, abs (\%) & $245(56.9)$ \\
\hline APACHE-II, $M \pm S D$ & $17.9 \pm 2.4$ \\
\hline SOFA, $M \pm S D$ & $8.7 \pm 1.9$ \\
\hline Time in ICU $\pm S D$, days & $5.4 \pm 1.6$ \\
\hline \multicolumn{2}{|l|}{ Nosology (ICD-10), abs (\%) } \\
\hline Traumas that cover body zones (T00-T07) & $123(28.7)$ \\
\hline Malignant neoplasms of the digestive system (C15-C26) & $62(14.5)$ \\
\hline Benign neoplasms (D10-D36) & $13(3.0)$ \\
\hline Echinococcosis (B67) & $7(1.6)$ \\
\hline Postcholecystectomy syndrome (K91.5) & $36(8.4)$ \\
\hline Achalasia of the cardial part of the oesophagus & $18(4.4)$ \\
\hline Septic and necrotic state of lower respiratory tracts (J85-J86) & $12(2.9)$ \\
\hline Crohn's disease (K50) & $10(2.4)$ \\
\hline Skin and skin structure infections (L00-L08) & $12(2.9)$ \\
\hline Paralytic ileus and intestinal obstruction without hernia (K56) & $8(1.9)$ \\
\hline Peritonitis (K65) & $73(17.0)$ \\
\hline Kidney abscess and paranephric body (N15.1) & $4(0.9)$ \\
\hline Pancreatonecrosis (K86.8.1) & $42(10.0)$ \\
\hline Other & $6(1.4)$ \\
\hline Total & $430(100.0)$ \\
\hline \multicolumn{2}{|l|}{ Co-morbidity, abs. (\%) } \\
\hline Ischemic heart disease (120-125) & $24(13.9)$ \\
\hline Hypertension disease (I11-|15) & $37(21.5)$ \\
\hline Atherosclerosis (170) & $31(18.2)$ \\
\hline Chronic disease of lower respiratory tracts (J40-J47) & $12(6.9)$ \\
\hline Adiposis (E66) & $10(5.8)$ \\
\hline Cachexia (R64) & $6(3.4)$ \\
\hline Diseases of gall bladder, bile passages and pancreas gland (K80-K87) & $52(30.2)$ \\
\hline Urinary stone disease (N20-N23) & $11(6.4)$ \\
\hline Prostatic Hyperplasia (N40) & $8(4.7)$ \\
\hline Iron deficiency anaemia (D50) & $13(7.6)$ \\
\hline Pancreatic diabetes (E10-E14) & $16(9.3)$ \\
\hline Other & $5(2.9)$ \\
\hline Total & $225(100.0)$ \\
\hline
\end{tabular}

the approach for preventing thromboembolic complications being demonstrated, a third of patients show a high probability of thromboembolic disorders [7]. In this regard, the main purpose of our work is to find a warning for PE development in non-cardiosurgical patients that have undergone intensive therapy under conditions of general surgical ICU, among the indicators of haemostasis system.

\section{Materials and Methods}

Based on anaesthesiology and emergency surgical department № 1 of the Kuvatov Republic Clinical Hospital (city of Ufa) the researchers carried out an analysis of the haemostasis system in 430 patients hospitalised over a four-year period between 2010 and 2014. The withdrawal criteria were verified hematologic pathology and the demonstrated fact of PE at the moment of admission to ICU. Advice in the organisation and planning of this study was provided by specialists at the Klinikum Dortmund gGmbH (Dortmund, Germany). The study was approved by the Ethics Committee of the State-Financed Educational Institution of Higher Professional Education Bashkir State Medical University of the Russian Health Ministry (No. 2 dated from 17/10/2010). Indicator values for the haemostasis system of the domiciled patients were derived from venous and arterial blood samples received prior to therapy during venous and arterial catheterisation in accordance with an intensive therapy plan and haemodynamic monitoring. The functional activity of platelets was studied using a Biola 230LA laser platelet aggregation analyser (Russia). The aggregation was induced by adenosine diphosphate (ADP) in a concentration of $20 \mu \mathrm{g} / \mathrm{ml}$, collagen at $5 \mathrm{mg} / \mathrm{ml}$, adrenaline at $5 \mu \mathrm{g} / \mathrm{ml}$ and ristomycin at $10 \mathrm{mg} / \mathrm{ml}$ (GOST, Russia). The definition of circulating aggregates was carried out using the $\mathrm{Wu}-\mathrm{Hoak}$ method as modified by F.H. Kohanna [8].

An STA Compact automated selective haemostasis analyser (Hoffmann - La Roche Ltd, France) registered indicators that characterise the state of endothelium, coagulation haemostasis element and marker medication of thrombosis and fibrinolysis affected by the test substances, enabling the following parameters to be determined: number of $\mathrm{D}$-dimers and antithrombin III (ATIII) activity. The work used original reagent kits produced by Roche Diagnostics (Hoffmann La Roche Ltd, France).

Thromboelastography was carried out using a TEG 5000 apparatus (Haemoscope Corporation, United States). The analysis of the thromboelastograms determined the general coagulation tendency $(\mathrm{R})$, the functional activity of platelets and fibrinogen (MA, Angle), fibrinolysis activity (CLT) and the physical-mechanical properties of the formed clots $(\mathrm{G})$. For the TEG activator, $0.2 \mathrm{M} \mathrm{CaCl}_{2}$ was used (GOST, Russia).

Statistical analysis. The findings were processed using the Statistica 10.0 statistical package (StatSoft Inc, USA). The normality of the actual data distribution was checked using the Shapiro - Wilk criterion. The groups were described using the median and interquartile interval. Variance analysis was performed using the Kruskal - Wallis (for independent observations) and Friedman (for repeated observations) test criteria. Dichotomous adverse peri- or postoperative 
outcome events were analysed using a uni- and multivariate logistic regression model with backwards stepwise elimination and are expressed as odds ratios (OR) and 95\% confidence intervals (CI). A $p$-value less than 0.05 was considered statistically significant.

\section{Results and Discussion}

The demographic and clinical profiles of the patients given in Table 1 show that general surgical and septic pathology prevails, accounting for $70.0 \%$ of the entire population sample. Comorbidity consisted of chronic diseases of the cardiovascular system (50\%), GIT (30\%) and lungs (16\%). During first day, $72.7 \%$ of patients had a sequential organ failure assessment (SOFA) score of 6 points or higher; in $13.1 \%$ of patients, the SOFA score was 12 points or higher.

Regarding hyperactivity of the haemostasis system at the moment of admission to ICU, patient screening showed that in $378(87.9 \%)$ patients the indicators of functional activity of platelets, coagulative marker medication of thrombosis and haemostasis were within the reference range and did not exhibit statistical differences for aerated and venous bloods (Tables 2-3). Among those patients having unimpaired haemostasiological indicators, there were no episodes of thrombotic complications recorded during hospitalisation.

$52(12.1 \%)$ patients showed homogeneous changes: this was associated with a $\mathrm{Wu}-$ Hoak value 15 times higher $(p \leq 0.01)$ compared to the test group both in aerated and venous blood. Thromboelastography data show hyperactivity of the thrombocytic component of haemostasis, i.e. the MA indicator increases on average by $46.9 \%$; the TMA indicator by $39 \%$ due to prolongation of clotting with hardening of the clot; while the $\mathrm{G}$ indicator increases by around 2.3 times relative to the control irrespective of the arterial and venous division of the blood stream. Indicators of platelet aggregation show hyper-aggregation in all inducers both in arterial and venous blood (Table 3). Using the method of interfacing tables with application of Pearson's chi-squared test, all patients with diagnosed episodes of thrombosis were allocated into the haemostasis system hyperactivity group $\left(\chi^{2}=3.875271, p=0.0027\right)$.

According to the results of the screening, all patients were divided into 2 groups: I $(n=378)$ - indicators of the haemostasis system without signs of hypercoagulation or hyperaggregation, and II $(n=52)$ - indicators of the haemostasis system without signs of hypercoagulation or hyperaggregation.

Univariate analysis showed a connection between nosocomial episodes of thrombosis and the following factors: emergency surgery (OR 9.1, $p<0.01$ ), peripheral vessel disease (OR 13.5, $p=0.01$ ), collapse development in pre-operation period (OR 30, $p<0.01$ ), high content of $\mathrm{D}$-dimers (OR 30, $p<0.01)$ and low content of AT III (OR 13.5, $p=0.01)$. Moreover, it is well-known that emergency operations and peripheral vascular disease [9-11] are associated with an increased operative risk [12-15] although the amount of risk involved as reported in the literature varies.

The results of multifactor analysis show that the significant diagnostic criteria are high content of D-dimers and low activity ATIII of venous blood (Tables 4 and 5).

\begin{tabular}{|c|c|c|c|c|}
\hline \multicolumn{2}{|c|}{ Indicator } & Vein & Artery & $p$ \\
\hline \multirow{5}{*}{1} & $\mathrm{R}, \mathrm{m}$ & $12.8(10.3-15.6)$ & $13.4(11.6-16.2)$ & 0.3 \\
\hline & TMA, min & $35.7(32.8-41.4)$ & $37.6(34.1-39.7)$ & 0.4 \\
\hline & $\mathrm{AF}, \mathrm{mm}$ & $57.3(54.2-61.2)$ & $54.1(50.6-59.8)$ & 0.6 \\
\hline & $\mathrm{G}$, dyne/cm² & 5.7 (4.5-7.9) & $5.1(4.2-7.8)$ & 0.4 \\
\hline & $\mathrm{CLT}, \min$ & 38.7 (35.4-42.4) & $36.4(35.6-41.5)$ & 0.7 \\
\hline \multirow{5}{*}{ II } & $\mathrm{R}, \mathrm{m}$ & 14.7 (11.5-18.3) & $15.2(13.7-17.6)$ & 0.2 \\
\hline & TMA, min & $21.7(19.4-23.1)^{*}$ & $22.9(18.4-23.4)^{* *}$ & 0.6 \\
\hline & $\mathrm{AF}, \mathrm{mm}$ & $84.2(79.6-87.1)^{* *}$ & $79.5(77.1-82.3)^{* *}$ & 0.3 \\
\hline & $\mathrm{G}$, dyne $/ \mathrm{cm}^{2}$ & $13.1(10.5-15.2)^{* *}$ & $11.8(9.6-13.2)^{* *}$ & 0.1 \\
\hline & CLT, $\min$ & $30.4(28.4-35.1)^{*}$ & $30.1(28.5-32.6)^{*}$ & 0.4 \\
\hline
\end{tabular}

Note: The statistical significance of the indication differences in comparison with the observational group were as follows: ${ }^{*}-p \leq 0.001,{ }^{* *}-p \leq 0.01 ; p-$ level of statistical significance of indicators differences between arterial and venous blood.

Table 2. Thromboelastography indicators, Me (25-75)

\begin{tabular}{|c|c|c|c|c|c|c|}
\hline Group & Blood & ADP, $\mathrm{mm}$ & Collagen, $\mathrm{mm}$ & Adrenaline, $\mathrm{mm}$ & Ristomicin, $\mathrm{mm}$ & Wu - Hoak, \% \\
\hline \multirow{2}{*}{ I } & Vein & $\begin{array}{c}46.5 \\
(36.3-54.1)\end{array}$ & $\begin{array}{c}43.2 \\
(38.5-54.7)\end{array}$ & $\begin{array}{c}41.5 \\
(37.2-51.3)\end{array}$ & $\begin{array}{c}48.9 \\
(37.5-53.6)\end{array}$ & $\begin{array}{c}1.1 \\
(0.0-1.7)\end{array}$ \\
\hline & Artery & $\begin{array}{c}47.5 \\
(44.1-56.1)\end{array}$ & $\begin{array}{c}48.1 \\
(37.8-53.2)\end{array}$ & $\begin{array}{c}37.2 \\
(31.5-43.9)\end{array}$ & $\begin{array}{c}44.6 \\
(37.1-48.9)\end{array}$ & $\begin{array}{c}0.8 \\
(0.0-1.3)\end{array}$ \\
\hline \multirow{2}{*}{ 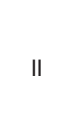 } & Vein & $\begin{array}{c}70.3 \\
(66.3-76.2)^{*}\end{array}$ & $\begin{array}{c}72.4 \\
(68.4-74.4)^{*}\end{array}$ & $\begin{array}{c}70.8 \\
(66.4-72.3)^{*}\end{array}$ & $\begin{array}{c}68.6 \\
(61.5-71.9)^{*}\end{array}$ & $\begin{array}{c}19.1 \\
(15.8-20.7)^{*}\end{array}$ \\
\hline & Artery & $\begin{array}{c}68.8 \\
(64.9-76.3)^{*}\end{array}$ & $\begin{array}{c}68.7 \\
(60.5-72.9)^{*}\end{array}$ & $\begin{array}{c}67.7 \\
(61.3-73.6)^{*}\end{array}$ & $\begin{array}{c}59.5 \\
(55.8-71.9)^{* *}\end{array}$ & $\begin{array}{c}18.0 \\
(15.8-19.8)^{*}\end{array}$ \\
\hline
\end{tabular}

Note: The level of statistical significance of the differences of indication in comparison with the observational group: ${ }^{*}-p \leq 0.001,{ }^{* *}-p \leq 0.01$. There is no difference between arterial and venous blood inside the group.

Table 3. Indicators of haemostasis system in the test group, Me (25-75)

\begin{tabular}{lcc}
\hline Group & D-dimers & AT III \\
\hline I & $0.05(0.03-0.07)$ & $84.9(81.5-90.7)$ \\
II & $2.4(1.1-2.7)^{* *}$ & $69.8(65.3-75.1)^{*}$ \\
Chi-square & 24.0 & 24.0 \\
\hline$p$-value & 0.000025 & 0.000113
\end{tabular}

Note: The level of statistical significance of the differences of indications in comparison with the observational group is as follows: ${ }^{*}-p \leq 0.001,^{* *}-p \leq 0.01$.

Table 4. Assessment of prognostic significance of D-dimers and ATIII activity in the development of embolia, Me (25-75)

\begin{tabular}{lccc}
\hline Indicator & Constant b 0 & AT III, \% & D-dimers \\
\hline Assessment & 0.530220 & 0.540 & -17.4085 \\
Odds ratio (measure units) & 1.699306 & 1.717 & $<0.00001$ \\
Odds ratio (range) & - & 9256.500 & $<0.00001$ \\
Note: $\mathrm{x}^{2}=29.062, p=0.00106, R^{2}=0.9123$. & & & \\
\hline
\end{tabular}

Table 5. Table of regression results 


\section{Conclusion}

Thus, the findings show that changes in the haemostasis system can function as a warning indicator for thrombotic complications during a period of hospital stay. The level of D-dimers and ATIII activity upon the results of the multifactor analysis comprises a warning for development of deep vein thrombosis and thromboembolia of the pulmonary artery for surgical patients. The findings enable the assessment of risks of patients with regard to the development of pulmonary embolism. The determination of high risks will in turn allow the occurrence of pulmonary embolism to be minimised and permit a timely assessment of the efficiency of preventive measures to be performed.

Conflict of interest.

The authors declare no conflict of interest.

Sponsorship data.

This work is not funded.

\section{References}

1 European Society of Cardiology. Guidelines on the diagnosis and management of acute pulmonary embolism. Eur Heart J. 2014;35:3033-80. DOI: 10.1093/eurheartj/ehu283

2 Caprini J.A., Glase S.J., Anderson C.B., Hathaway K. Laboratory markers in the diagnosis of venous thromboembolism. Circulation. 2004;109:I-4-I-8. DOI: 10.1161/01.CIR.0000122869.59485.36

3 Kodiatte T.A., Manikyam U.K., Rao S.B., Jagadish T.M., Reddy M., Lingaiah H.K.M., et al. Mean platelet volume in type 2 diabetes mellitus. J Lab Physicians. 2012;4(1):5-9. DOI: 10.4103/0974-2727.98662

4 Kuderer N.M., Poniewierski M.S., Culakova E., Lyman G.H., Khorana A.A., Pabinger I., et al. Predictors of venous thromboembolism and early mortality in lung cancer: results from a Global Prospective Study (CANTARISK). Oncologist. 2018;23(2):247-55. DOI: 10.1634/ theoncologist.2017-0205

5 Etzioni D.A., Lessow C., Bordeianou L.G., Kunitake H., Deery S.E. Carchman E., et al. Venous thromboembolism after inpatient surgery in administrative data vs NSQIP: a multi-institutional study. J Am
Coll Surg. 2018;S1072-7515(18)30123-6. DOI: 10.1016/j.jamcollsurg.2018.01.053

6 Freund Y., Cachanado M., Aubry A., Orsini C., Raynal P.A., FéralPierssens A.L., et al. Effect of the pulmonary embolism rule-out criteria on subsequent thromboembolic events among low-risk emergency department patients: The PROPER randomized clinical trial. JAMA 2018;13;319(6):559-66. DOI: 10.1001/jama.2017.21904

7 Pasrija C., Kronfli A., Rouse M., Raithel M., Bittle G.J., Pousatis S. et al. Outcomes after surgical pulmonary embolectomy for acute submassive and massive pulmonary embolism: a single-center experience. J Thorac Cardiovasc Surg. 2018;155(3):1095-1106.e2. DOI: 10.1016/j. jtcvs.2017.10.139

8 Kohanna F.H., Smith M.H., Salzman E.W. Do patients with thromboembolic disease have circulating platelet aggregates? Blood. 1984;64(1):205-09. PMID: 6733272

9 Ozdemir B.A., Sinha S., Karthikesalingam A., Poloniecki J.D., Pearse R.M., Grocott M.P., Thompson M.M., Holt P.J. Mortality of emergency general surgical patients and associations with hospital structures and processes. Br J Anaesth. 2016;116(1):54-62. DOI: 10.1093/bja/aev372. PMID: 26675949

10 McCallum I.J., McLean R.C., Dixon S., O’Loughlin P. Retrospective analysis of 30-day mortality for emergency general surgery admissions evaluating the weekend effect. Br J Surg. 2016;103(11):1557-65. DOI: 10.1002/bjs.10261

11 Fitzgerald J.E.F., Khatri C., Glasbey J.C., Mohan M., Lilford R., Harrison E.M., et al. Mortality of emergency abdominal surgery in high-, middle- and low-income countries. Br J Surg. 2016;103(8):971-88. DOI: $10.1002 /$ bjs. 1015

12 Symons N.R.A., Moorthy K., Almoudaris A.M., Bottle A., Aylin P. Vincent C.A., et al. Mortality in high-risk emergency general surgical admissions. Br J Surg. 2013;100(10):1318-25. DOI: 10.1002/bjs.9208

13 Sinha S., Karthikesalingam A., Poloniecki J.D., Thompson M.M., Holt P.J. Inter-relationship of procedural mortality rates in vascula surgery in England retrospective analysis of hospital episode statistics from 2005 to 2010. Circ Cardiovasc Qual Outcomes. 2014;7:131-41. DOI: 10.1161/CIRCOUTCOMES.113.000579

14 Ozdemir B.A., Karthikesalingam A., Sinha S., Poloniecki J.D., VidalDiez A., Hinchliffe R.J., et al. Association of hospital structures with mortality from ruptured abdominal aortic aneurysm. Br J Surg. 2015;102(5): 516-24. DOI: 10.1002/bjs.9759

15 Qiu C., Chan P.H., Zohman G.L., Prentice H.A., Hunt J.J., LaPlace D.C., et al. Impact of anesthesia on hospital mortality and morbidities in geriatric patients following emergency hip fracture surgery. J Orthop Trauma. 2018;32(3):116-23. DOI: 10.1097/BOT.0000000000001035 